\title{
Nonenzymatic Release of Intact Protoplasts from Mature Pollen of Bean
}

\author{
M.L. Weaver, V. Breda, and W. Gaffield \\ U.S. Department of Agriculture, Agricultural Research Service, Western Regional Research Center, \\ Albany, CA 94710
}

\author{
H. Timm \\ Department of Vegetable Crops, University of California, Davis, CA 95616 \\ Additional index words. dilute salt solutions, protoplasm viability, cell wall-degrading enzymes, Phaseolus vulgaris
}

\begin{abstract}
A nonenzymatic technique using dilute salt solutions effected rapid release of viable protoplasts from mature bean (Phaseolus vulgaris L.) pollen. Protoplasm release started within $30 \mathrm{sec}$ and was completed within 5 min in solutions of 0.02 to $0.06 \mathrm{~m} \mathrm{NaCl}$, or $\mathrm{KCl}$, pH 6 to 9 . The degree of release could be altered by changing the concentrations and ratios of $\mathrm{CaCl}_{2}$ and $\mathrm{H}_{3} \mathrm{BO}_{3}$ and by adding sucrose to either solidified or aqueous salt media. The surface of nonenzymatically released protoplasts was partially digested by short-time exposure to a mixture of cell wall-degrading enzymes and then examined by scanning electron microscope.
\end{abstract}

Protoplasts were first released from leaf segments plasmolyzed in $\mathrm{KNO}_{3}$ (Klerker, 1892). A few cells were cut without apparent damage to the protoplasts, and intact protoplasts were released by controlled deplasmolysis. Kuster (1909) used an aqueous solution of $\mathrm{Ca}\left(\mathrm{NO}_{3}\right)_{2}$ to produce subprotoplasts. In another study (Michel, 1937), leaf tissue was pretreated with $\mathrm{KNO}_{3}$, then mechanically cut and protoplasts released using a viscous solution of sucrose. Protoplasts can be mechanically released only from cells in which a high degree of plasmolysis occurs followed by subsequent separation from the cell wall. Mechanical release, however, is slow, with recovery of relatively few intact protoplasts.

Large quantities of intact protoplasts are released using cell wall-degrading enzymes (Power and Cocking, 1969; Takebe et al., 1968). A major concern in the use of this method, however, is the potential damage to the physical structure and physiological activity of the protoplasts. Pilet $(1972,1973)$, using a few protoplasts mechanically released from root cells of Allium cepa, found that cell wall-degrading enzymes reduced transaminase activity. Research efforts to identify other potentially harmful effects have lagged, however, because of the inability to nonenzymatically release the large quantities of intact protoplasts needed for such studies.

Although intact protoplasts can be released enzymatically from somatic cells of most plant tissues, release from pollen grains presents special problems. At the immature tetrad stage, cell walls are only partially susceptible to enzymatic degradation (Bhojwani and Cocking, 1972; Deka et al., 1977), and release requires as long as $30 \mathrm{hr}$ (Redenbaugh et al., 1980). The cell wall of mature pollen, however, contains sporopollenin, one of the most chemically inert natural plant constituents known (Gheradini and Healey, 1969) and one that is totally resistant to all of the commonly used cell wall-degrading enzymes. Baldi et al. (1985) released pollen protoplasts using a polysaccharide solvent, but the procedure required a very high temperature (75C) that reduced viability.

This study describes a unique, rapid process for the nonenzymatic release of intact viable protoplasts from mature bean pollen, and shows microscopic observations on physical alter-

Received for publication 17 Apr. 1989. The cost of publishing this paper was defrayed in part by the payment of page charges. Under postal regulations, this paper therefore must be hereby marked advertisement solely to indicate this fact. ations to the surface of nonenzymatically released protoplasts by a mixture of enzymes.

\section{Materials and Methods}

Plants of 'Monroe' bean were grown in commercial planting medium (Fisons Sunshine mixture, Fisons Western, Vancouver, Canada) in 4.5-liter clay pots in a greenhouse at $25 / 21 \mathrm{C}$ (day/ night), with a coincident photoperiod of 14/10 hr (day/night). Freshly opened flower buds were collected between $0730 \mathrm{HR}$ and $0930 \mathrm{HR}$. Within $5 \mathrm{~min}$ of collection, pollen from each flower was shaken into the well of a $0.4 \times 1.2-\mathrm{cm}$ microcavity slide, followed immediately by the addition of two drops of an experimental protoplasm-release solution that contained various concentrations and combinations of $\mathrm{NaCl}, \mathrm{KCl}, \mathrm{CaCl}_{2}$, and $\mathrm{H}_{3} \mathrm{BO}_{3}$ in glass-distilled water. Slides were then placed in closed chambers at $25 \mathrm{C}$ and $98 \% \mathrm{RH}$. Osmotic stabilizers, sucrose $(0.03$ to $1.2 \mathrm{M})$, mannitol $(0.03$ to $1.2 \mathrm{M})$, and sorbitol $(0.03$ to $1.0 \mathrm{M})$, were included along with the protoplast-release solutions to evaluate their influence on both quantity and extent of release and on prolonged stability of the released protoplasts. The $\mathrm{pH}$ of the release solutions was adjusted between 5.0 and 9.0 using $1.0 \mathrm{~N} \mathrm{HCl}$ or $1.0 \mathrm{~N} \mathrm{KOH}$. In other trials, the same solutions were solidified with $0.5 \%$ or $1.0 \%$ agar. Pollen was shaken onto the surface of agar medium in a $9.0 \times 1.0-\mathrm{cm}$ petri dish and covered with a drop of phloxine/methyl green dye (Owczarzak, 1952).

The total number of pollen grains from which protoplasts were released and the number of those totally released from the cell wall were determined microscopically $5 \mathrm{~min}$ after pollen application. The extent of protoplasm release was recorded as: 1) total, the number of pollen grains showing protoplasm release (partial plus free); and 2) free (Fig. 1B), protoplasts totally removed from the cell wall. Figure 2 shows several intact protoplasts from one treatment.

Each treatment mean included pollen from a minimum of 12 flowers picked at random, replicated three times, and repeated six times during a period of 30 days. At least 500 pollen grains were evaluated from each flower. All data were statistically evaluated by analysis of variance and treatment means were compared by LSD at $P=0.05$ (Snedecor, 1956).

Viability of released protoplasts was determined using methylene blue (Vairo, 1961) and fluorescein diacetate (Heslop-Harrison and Heslop-Harrison, 1970).

To investigate the possible physical alteration of pollen pro- 


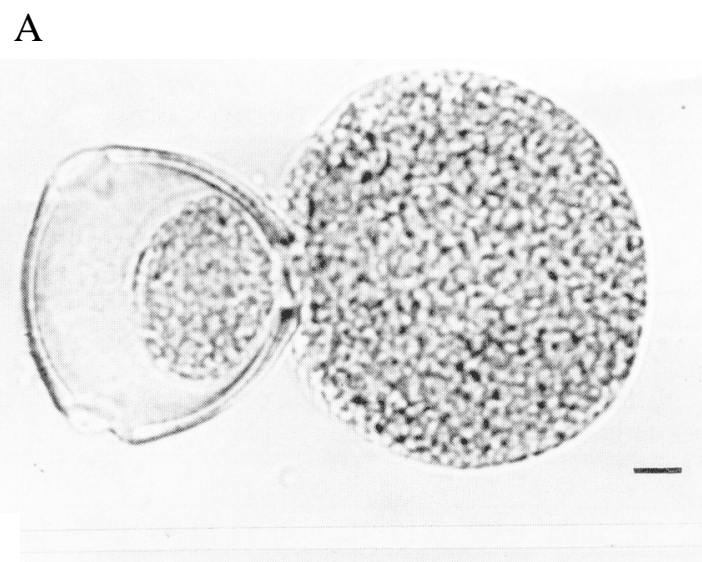

B

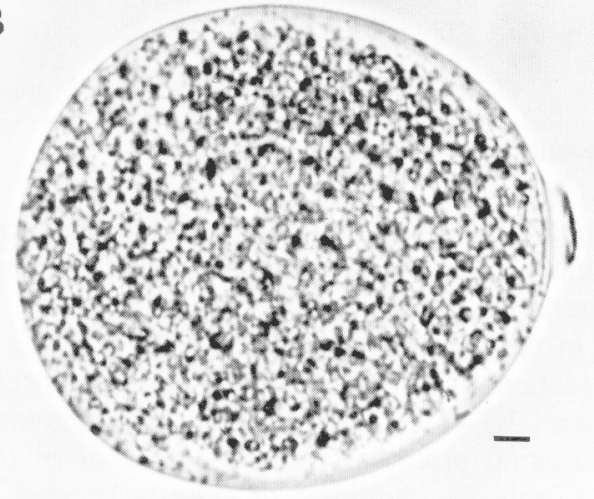

Fig. 1. (A) Bean pollen protoplasm partially released after $55 \mathrm{sec}$ in $0.03 \mathrm{M} \mathrm{NaCl}+1.0$ м sucrose, $\mathrm{pH}$ 6.5. Bar $=5 \mu \mathrm{m}$. (B) $\mathrm{S}$ a me bean pollen protoplasm totally free from the cell wall after $60 \mathrm{sec}$.

toplasts by cell wall-degrading enzymes, pollen from each of 20 freshly opened bean flowers was shaken into the wells of two microcavity slides and covered with two drops of protoplast-release solution containing $0.03 \mathrm{M} \mathrm{NaCl}, 300 \mathrm{mg} \mathrm{CaCl} /$ liter, $100 \mathrm{mg} \mathrm{H}_{3} \mathrm{BO}_{3}$ /liter, and $0.29 \mathrm{~m}$ sucrose at $\mathrm{pH}$ 6.5. After 5 rein, a drop of protoplasm-release solution containing $1 \%(\mathrm{w} /$ v) Rhozyme HP-150 (Rohm and Haas, Philadelphia), 1\% (w/ v) cellulase R-10 and 1\% (w/v) Macerozyme R-10 (both from Kinki Yokut Biochemical, Nishinomiya, Japan) was added to one slide and one drop of the protoplasm-release solution without enzymes was added to another slide. After $15 \mathrm{~min}$ at $25 \mathrm{C}$, pollen from each slide was washed with the same protoplast-release solution into separate 3-ml centrifuge tubes and centrifuged (4 $\min$ in a Sorvall GLC-1 with a relative centrifugal force of $45 \times$ $\mathrm{g})$. The wash solution was poured off, and the washing procedure was repeated. A drop of solution containing washed protoplasts from enzyme-free or enzyme-treated solutions was frozen in $\mathrm{N}_{2}$ slush and transferred under vacuum using a Hexland CT 1000A Cryo unit (East Challow, Oxfordshire, England) for viewing in a Hitachi S-530 scanning electron microscope.

\section{Results and Discussion}

In nature, pollen hydrates within seconds of contacting the stigma. Water absorbed by the pollen from the stigma exerts a pressure on the interior of the cell wall. Because the outer layer covering the pore of the pollen is weaker than the cell wall, it

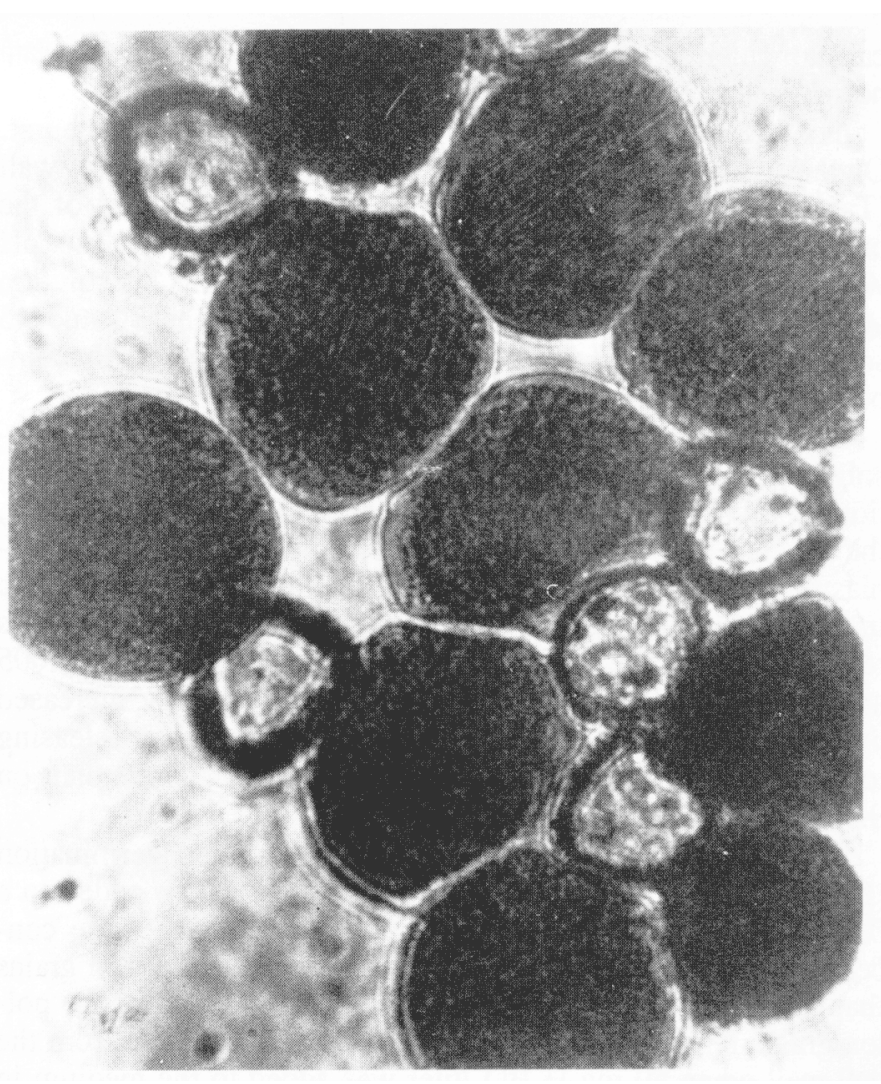

Fig. 2. Several bean pollen protoplasts released after $5 \mathrm{~min}$ in the same $\mathrm{NaCl}$ solution described in Fig. 1A above.

Table 1. Influence of salt concentration at $\mathrm{pH} 6.0$ on release of bean pollen protoplasts.

\begin{tabular}{|c|c|c|c|c|c|c|c|}
\hline \multirow{2}{*}{$\begin{array}{l}\text { Protoplast } \\
\text { release }\end{array}$} & \multicolumn{7}{|c|}{ Salt concentration (M) } \\
\hline & 0 & 0.01 & 0.02 & 0.04 & 0.06 & 0.08 & 0.10 \\
\hline & \multirow{2}{*}{\multicolumn{7}{|c|}{ Intact protoplasts released (no./100 pollen grains) }} \\
\hline \multicolumn{6}{|l|}{$\mathrm{NaCl}$} & & \\
\hline Total & 20 & 91 & 90 & 91 & 92 & 75 & 50 \\
\hline Free ${ }^{z}$ & 20 & 68 & 85 & 85 & 84 & 60 & 0 \\
\hline $\operatorname{LSD}_{0.05}$ & NS & 6 & 6 & 6 & 6 & 8 & 7 \\
\hline \multicolumn{8}{|l|}{$\mathrm{KCl}$} \\
\hline Total & 20 & 89 & 88 & 87 & 85 & 70 & 45 \\
\hline Free $^{z}$ & 20 & 66 & 85 & 82 & 79 & 55 & 0 \\
\hline $\mathrm{LSD}_{0.05}$ & NS & 6 & 6 & 6 & 6 & 6 & 6 \\
\hline
\end{tabular}

'Protoplasts totally free from the cell wall.

ruptures, and the protoplasm protrudes through the pore initiating pollen tube growth. We believed that if this naturally occurring process could be greatly accelerated, the entire protoplasm could be removed from within the cell wall in seconds.

Bean pollen hydrated rapidly in glass-distilled water, but most protoplasts (i.e., $80 \%$ ) ruptured (Table 1). In $0.01 \mathrm{M} \mathrm{NaCl}$ solution, intact protoplasts were released from almost all pollen grains; however, of those released only $\approx 75 \%$ were totally free from the cell wall. With 0.02 to $0.06 \mathrm{M} \mathrm{NaCl}$, a little more than $90 \%$ of the protoplasts released were totally free of the cell wall. At a salt concentration of $0.08 \mathrm{M}$, the percentage of pollen grains that released totally free intact protoplasts had decreased to $80 \%$, and at $0.10 \mathrm{~m}$ none of the protoplasts released were totally free from the cell wall. Potassium chloride solutions of the same molarity as $\mathrm{NaCl}$ gave similar results in protoplasm release (Table 1). Even very low concentrations $(<0.005 \mathrm{M})$ of supplemental 
calcium chloride totally prevented the release of protoplasts (data not shown).

In a $0.03-\mathrm{M} \mathrm{NaCl}$ solution at $\mathrm{pH} 5.0$, many protoplasts burst. Of those still intact, $38 \%$ were totally free from the cell wall (Table 2). Few protoplasts ruptured, and essentially all of the protoplasts released were totally free from the cell wall as $\mathrm{pH}$ was increased from 6.0 through 9.0 . In a $0.03-\mathrm{M} \mathrm{NaCl}$ solution at $\mathrm{pH}$ 6.0, protoplasm release commenced between 30 and 45 sec after contact with the solution. Release was essentially completed within $5 \mathrm{~min}$.

Total number of pollen that released intact protoplasts in agarsolidified salt media (Table 3) was similar to that obtained in liquid (Table 1) media at the same concentration. On $0.5 \%$ agar, the number of pollen grains releasing totally free intact protoplasts was significantly increased with each increment increase in salt concentration. On $1.0 \%$ agar, only a few pollen grains released totally free intact protoplasts when subjected to 0.005 and $0.01 \mathrm{M} \mathrm{NaCl}$, but the number was significantly increased by 0.02 and $0.04 \mathrm{M} \mathrm{NaCl}$. The number of pollen grains releasing totally free intact protoplasts was much less on $1.0 \%$ than on $0.5 \%$ agar at similar salt concentrations.

Boron and $\mathrm{Ca}$ are deemed essential to pollen germination (Brewbaker and Kwack, 1963; Vasil, 1964). When added to a $0.03-\mathrm{M} \mathrm{NaCl}$ solution at $\mathrm{pH} 6.0$, neither element, at the concentrations used, greatly altered the total number of pollen grains that released intact protoplasts (Table 4). Almost all of the pollen grains releasing intact protoplasts were totally free from the cell wall when $50 \mathrm{mg} \mathrm{H}_{3} \mathrm{BO}_{3}$ /liter was added to the medium in the absence of supplemental Ca. Addition of 100 and $200 \mathrm{mg}$ $\mathrm{H}_{3} \mathrm{BO}_{3}$ /liter in the absence of supplemental $\mathrm{CaCl}_{2}$ resulted in a significant decrease in the number of pollen grains releasing protoplasts that were totally free from the cell wall. In the absence of supplemental $\mathrm{H}_{3} \mathrm{BO}_{3}$, addition of $\mathrm{CaCl}_{2}$ at $50 \mathrm{mg} \cdot \mathrm{liter}^{-1}$ resulted in $82 \%$ of the protoplasts from pollen that released intact protoplasts being totally free from the cell wall. Addition of 100 and $300 \mathrm{mg} \mathrm{CaCl} /$ liter significantly reduced the percentage of totally free intact protoplasts to $30 \%$ and $4 \%$, respectively. When $\mathrm{CaCl}_{2}$ and $\mathrm{H}_{3} \mathrm{BO}_{3}$ were used together, the

Table 2. Influence of $\mathrm{pH}$ on the release of bean pollen protoplasts in a $0.03-\mathrm{M} \mathrm{NaCl}$ solution.

\begin{tabular}{|c|c|c|c|c|c|}
\hline \multirow{2}{*}{$\begin{array}{l}\text { Protoplast } \\
\text { release }\end{array}$} & \multicolumn{5}{|c|}{$\mathrm{pH}$} \\
\hline & $\overline{5.0}$ & 6.0 & 7.0 & 8.0 & 9.0 \\
\hline & \multicolumn{5}{|c|}{ Intact protoplasts released (no. 1100 pollen grains) } \\
\hline Total & 65 & 95 & 88 & 89 & 83 \\
\hline Free $^{z}$ & 25 & 90 & 84 & 85 & 80 \\
\hline $\mathrm{LSD}_{0.05}$ & 7 & NS & NS & NS & NS \\
\hline
\end{tabular}

${ }^{2}$ Protoplasts totally free from the cell wall.

${ }^{\mathrm{Ns}}$ Nonsignificant.

Table 3. Influence of salt concentration on release of bean pollen protoplasts in agar-solidified medium at $\mathrm{pH}$ 6.0.

\begin{tabular}{lccccccccc}
\hline & \multicolumn{8}{c}{$\mathrm{NaCl}(\mathrm{M})$} \\
\cline { 2 - 9 } & \multicolumn{10}{c}{0.005} & \multicolumn{7}{c}{0.01} & 0.02 & 0.04 \\
\cline { 2 - 9 } Protoplast & \multicolumn{8}{c}{ Agar (\%) } \\
\cline { 2 - 9 } release & 0.5 & 1.0 & 0.5 & 1.0 & 0.5 & 1.0 & 0.5 & 1.0 \\
\hline \multicolumn{8}{c}{ Intact protoplasts } & released & (no./100 pollen grains) \\
Total & 85 & 80 & 81 & 87 & 82 & 86 & 79 & 81 \\
Free $^{\mathrm{z}}$ & 25 & 5 & 45 & 7 & 60 & 18 & 68 & 16 \\
LSD $_{0.05}$ & 6 & 7 & 7 & 6 & 7 & 7 & 7 & 6 \\
\hline
\end{tabular}

${ }^{2}$ Protoplasts totally free from the cell wall.
Table 4. Influence of supplemental $\mathrm{CaCl}_{2}$ and $\mathrm{H}_{3} \mathrm{~B} \mathrm{O}$ on the release of bean pollen protoplasts in $0.03-\mathrm{M} \mathrm{NaCl}$ solution at $\mathrm{pH} 6.0$.

\section{Salt and concn}

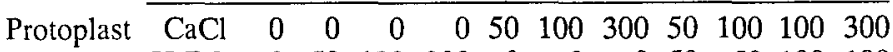

\begin{tabular}{|c|}
\hline release \\
\hline
\end{tabular}

Intact protoplasts released (no./100 pollen grains)

$\begin{array}{lrrrrrrrrrrr}\text { Total } & 86 & 85 & 90 & 86 & 85 & 90 & 85 & 85 & 90 & 85 & 88 \\ \text { Free }^{z} & 82 & 81 & 63 & 60 & 70 & 30 & 3 & 77 & 85 & 30 & 2 \\ \text { LSD }_{0.05} & 6 & 6 & 6 & 6 & 6 & 7 & 7 & 6 & 6 & 7 & 7\end{array}$

${ }^{2}$ Protoplasts totally removed from the cell wall.

Table 5. Effect of sucrose concentration on the release of bean pollen protoplasts in $0.03-\mathrm{M} \mathrm{NaCl}$ solution at $\mathrm{pH} 6.0$.

\begin{tabular}{lrrrrrrrrrr}
\hline \hline Protoplast & \multicolumn{10}{c}{ Sucrose (M) } \\
\cline { 2 - 11 } release & 0 & 0.03 & 0.09 & 0.15 & 0.29 & 0.44 & 0.58 & 0.73 & 0.88 & 1.17 \\
\hline \multicolumn{1}{c}{ Intact } & protoplasts released (no./100 & pollen & grains) \\
Total & 80 & 90 & 92 & 90 & 88 & 80 & 75 & 76 & 75 & 71 \\
Free $^{\mathrm{z}}$ & 78 & 87 & 88 & 86 & 85 & 75 & 50 & 41 & 25 & 11 \\
LSD $_{0.05}$ & 7 & 7 & 7 & 7 & 7 & 7 & 6 & 6 & 6 & 6 \\
\hline
\end{tabular}

xprotoplasts totally released from cell wall.

reaction of pollen to release of totally free intact protoplasts was similar to that of pollen given only supplemental $\mathrm{CaCl}_{2}$ at the same concentration.

Sucrose, in the absence of $\mathrm{NaCl}$, did not effect a release of protoplasts (data not shown). However, addition of 0.03 to 0.29 $\mathrm{M}$ sucrose to a $0.03-\mathrm{M} \mathrm{NaCl}$ solution increased the total number of pollen-releasing protoplasts and the number of totally free protoplasts (Table 5). Addition of 0.44-M sucrose decreased both the total number of pollen releasing intact protoplasts and the number of totally free protoplasts. The number of pollen releasing intact protoplasts then remained the same with additions of 0.58 to $1.17 \mathrm{M}$ sucrose. The percentage of pollen grains releasing totally free intact protoplasts, however, was significantly decreased with each successive increment increase of sucrose from 0.58 through $1.17 \mathrm{M}$.

Although sugars and sugar alcohols are preferred protoplasm stabilizers, salts can also be used (Meyer, 1974). However, protoplasts take up salt, and prolonged exposure to salt can be injurious. With the process described in this study, however, protoplasm release was so rapid ( $<5 \mathrm{~min})$ that potential salt damage would be minimized.

Mannitol concentrations at 0.3 to $15.0 \mathrm{M}$ and sorbitol at 0.3 to $1.0 \mathrm{M}$ in dilute salt solutions did not alter the total number of pollen grains releasing intact protoplasts or the viability of protoplasts when compared to similar dilute salt solutions without sorbitol or mannitol (data not shown).

At least $80 \%$ of the protoplasts released in 0.02 to $0.06-\mathrm{M}$ $\mathrm{NaCl}$ solutions retained their viability for at least $16 \mathrm{hr}$, as determined by methylene blue (Vairo, 1961) and by FDA (Heslop-Harrison and Heslop-Harrison, 1970).

Although only totally free protoplasts were evaluated in the study, partially free protoplasts (Fig. 1A) are of special interest, since they are less fragile and leave less cellular debris to interfere with microscopic examination. When sufficient protoplasm surface is exposed, they could prove useful for fusion and for transfer of genetic material by microinjection or electroporation. Although not shown in any of the tables, partials make up a large portion of the total protoplasts released. The number of partials produced and the amount of protoplasm release can be regulated by controlling the concentration of $\mathrm{CaCl}_{2}, \mathrm{H}_{3} \mathrm{BO}_{3}$, 
and sucrose used in the dilute salt solution and by controlling agar concentration.

All nonenzymatically released protoplasts, both totally free and partially free, remained intact. When nonenzymatically released protoplasts were incubated with cell wall-degrading enzymes, few $(<5 \%)$ remained intact.

Exposure of nonenzymatically released protoplasts (Fig. 3A) to cell wall-degrading enzymes resulted in a severe disintegration of the protoplasm surface (Fig. 3B). The surface of a protoplast contains large quantities of carbohydrate constituents (Williamson et al., 1976), and their loss through enzymatic degradation could be detrimental to the function and longevity
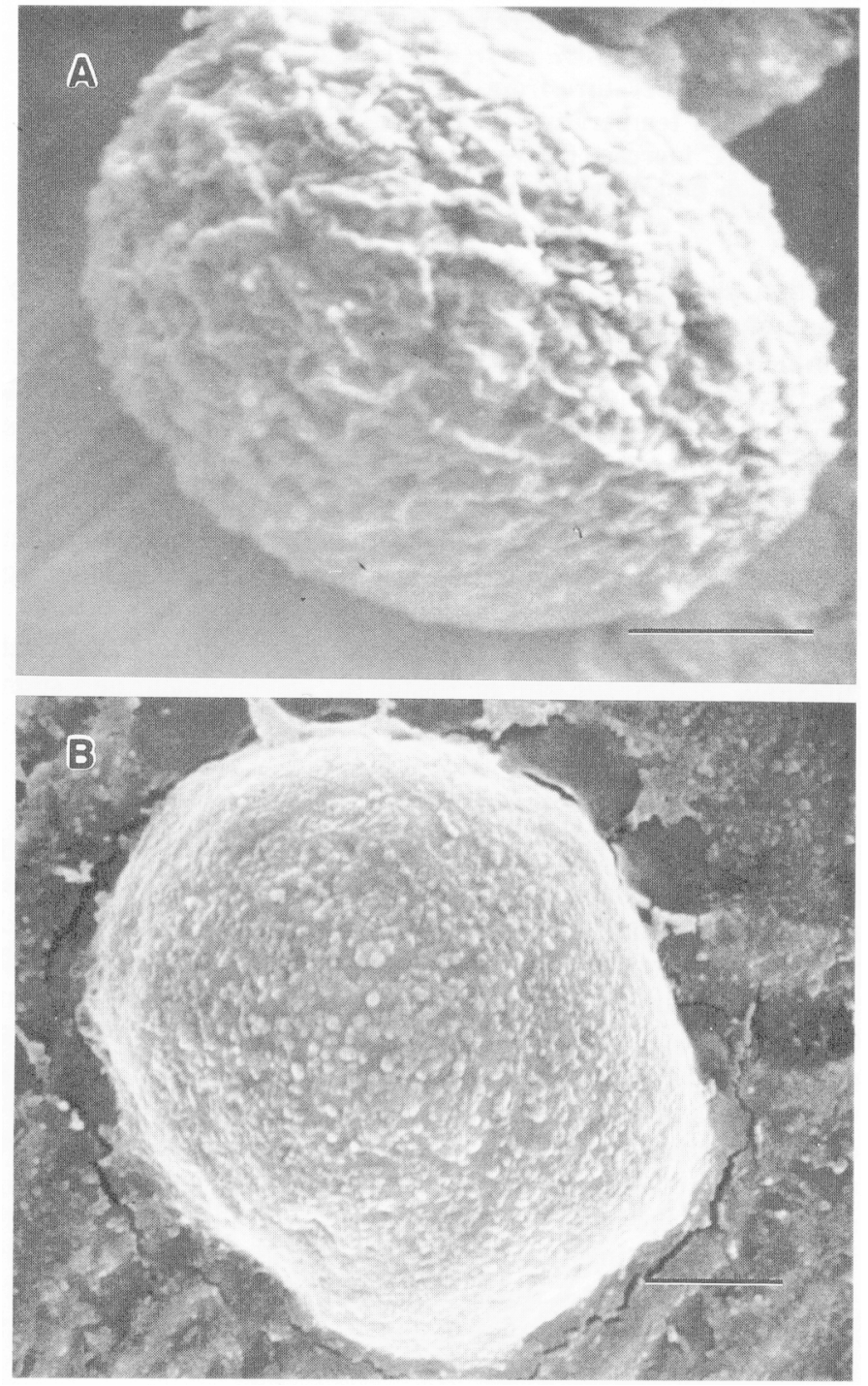

Fig. 3. (A) Bean pollen protoplasm released as in Fig. 2 above. One drop of the solution containing protoplasts was frozen in $\mathrm{N}$ slush and transferred under vacuum using a Hexland CT 1000A Cryotrans unit for viewing in a Hitachi S-530 scanning electron microscope (SEM). Bar $=5 \mu \mathrm{m}$. (B) Bean pollen protoplasm released as above and then subjected to an enzyme containing $1 \%$ each Rhozyme HP150, cellulase R-10, and macerozyme $\mathrm{R}-10$ at $\mathrm{pH} 6.5$, for $15 \mathrm{~min}$. One drop of the solution containing protoplasts was treated with $\mathrm{N}$ slush and examined by SEM as described in A above, except that the sample was left overnight in the SEM and viewed the next day. of the protoplasm and could influence in vitro plant regeneration. Cell wall-degrading enzymes also release wall-bound enzymes such as peroxidase and catalase (Vairo, 1961; Strand et al., 1976), which could alter physiological processes associated with the protoplasm.

This study demonstrates for the first time that large quantities of viable intact protoplasts can be rapidly released from mature bean pollen without the use of cell wall-degrading enzymes. These results suggest the intriguing possibility that plants can be regenerated from mature pollen protoplasts. This procedure for nonenzymatically released protoplasts could be used for genetic manipulation through somatic hybridization and genetic transformation.

\section{Literature Cited}

Baldi, B.G., V.R. Fransceschi, and F. Loewus. 1985. Pollen sporoplasts. Plant Physiol. (Suppl.) 77:71. .

Bhojwani, S.S. and E.C. Cocking. 1972. Isolation of protoplasts from pollen tetrads. Nature New Biol. 239:29-30.

Brewbaker, J.L. and B.H. Kwack. 1963. Essential role of calcium ion in pollen germination and pollen tube growth. Amer. J. Bot. 50:859865.

Deka, P.C., A.K. Mehra, N.N. Pathak, and S.K. Sen. 1977. Isolation and fusion studies on protoplasts from pollen tetrads. Experiential 33:182-184.

Gherardini, G.L. and P.L. Healey. 1969. Dissolution of outer wall of the pollen grain during pollination. Nature (London) 224:218-219.

Heslop-Harrison, J. and Y. Heslop-Harrison. 1970. Evaluation of pollen viability by enzymatically induced fluorescence. Intracellular hydrolysis of fluorescein diacetate. Stain Technol. 45:115-120.

Klerker, J.A.F. 1892. Eine Methode zur isolierung lebender protoplasten. Oefoers. Betensk. Akad. Forh. Stokh. 9:463-471.

Kuster, E. 1909. Über die Verschmelzung nachter Protoplasten. Ber. Dtsch. Bot. Ges. 27:589-598.

Meyer, Y. 1974. Isolation and culture of tobacco mesophyll protoplasts using saline medium. Protoplasm 81:363-372.

Michel, W. 1937. Über die experimentelle Fusion pflanzlicher Protoplasten. Arch. Exp. Zellforsch. Bas. Geweb. 20:230-252.

Owczarzak, A. 1952. A rapid method of mounting pollen grains. Stain Technol. 27:249-251.

Pilet, P.E. 1972. Transaminase activities of root protoplasts. Experientia 28:638-639.

Pilet, P.E. 1973. Effect of wall-degrading enzymes on protoplasts transaminase activity. Experiential 29:1206-1207.

Power, J.B. and E.C. Cocking. 1969. A simple method for the isolation of very large numbers of leaf protoplasts by using mixtures of cellulase and pectinase. Biochem. J. 111:33.

Redenbaugh, M.K., R.D. Westfall, and D.F. Karnosky. 1980. Protoplast isolation from Ulmus americana L. pollen mother cells, tetrads and microspore. Can. J. For. Res. 10:284-289.

Snedecor, G.W. 1956. Statistical methods. Iowa State Univ. Press, Ames.

Strand, L.L., C. Rechtoris, and H. Mussell. 1976. Polygalacturonases release cell-wall bound proteins. Plant Physiol. 58:722-725.

Takebe, I., Y. Otsuki, and S. Aoki. 1968. Isolation of tobacco mesophyll cells in an intact and active state. Plant Cell Physiol. 9:115124.

Vairo, M.L.R. 1961. Methylene blue solutions for staining dead yeast cells. Stain Technol. 36:329-330.

Vasil, I.K. 1964. Effect of boron on pollen germination and pollen tube growth, p. 107-119. In: H.F. Linskens (ed.). Pollen physiology and fertilization. North Holland, Amsterdam.

Williamson, F.G., L.C. Fowke, F. Constabel, and O.L. Gamborg. 1976. Labeling of concanavalin-A sites on the plasma membrane of soybean protoplasts. Protoplasma 89:305-316. 